\title{
Taxonomic notes on the broad-leaved paperbarks (Myrtaceae, Melaleuca), including the description of one new species from northern Australia and a key to all taxa
}

\author{
L.A. Craven ${ }^{1}$, I.D. Cowie ${ }^{2}$
}

Key words

identification key

M. ferruginea

M. nervosa

Melaleuca

Myrtaceae

taxonomy
Abstract Melaleuca ferruginea is newly described, $M$. nervosa subsp. crosslandiana is reduced to $M$. nervosa, and an amended identification key is provided for the $M$. leucadendra species group.

Published on 3 January 2013

\section{INTRODUCTION}

Species of the Melaleuca leucadendra (L.) L. group of species, the broad-leaved paperbark group, are a distinctive feature of the northern Australian landscape. Occurring in seasonally wet woodlands, swamps, or riparian and swamp forest, the relevant species often form a monospecific tree component of the vegetation. Species are segregated in the environment by sometimes subtle variation in soil texture and depth and period of flooding while temporal differences in flowering may effect reproductive isolation. An enumeration of the then known species of the group was given in Craven (1999). Recent molecular work (Edwards et al. 2010) indicates that M. cornucopiae Byrnes, treated by Craven (1999) as a member of the broad-leaved paperbark group, does not belong there. Due to excessive morphological overlap with the typical subspecies, $M$. nervosa subsp. crosslandiana (W.Fitzg.) Barlow ex Craven should be included in that taxon, i.e., no infraspecific taxa are now being recognised within $M$. nervosa (Lindl.) Cheel. Following reconsideration of some anomalous specimens from floodplain and swamp habitats of the Northern Territory, a further species of broad-leaved paperbark is newly described below. A revised identification key to the complex is provided.

\section{Melaleuca ferruginea Craven \& Cowie, sp. nov.}

Differt a M. leucadendra (L.) L. ramulis foliisque trichomatibus pubescentibus lanuginulosisque, hypanthio longiore (3-4 mm longo), et lobis calycis latissime triangularibus. - Typus: Cowie 7335 (holo CANB; iso AD, BRI, DNA, K, MEL, NSW, NY, PERTH, QRS), in dune swale, c. $22 \mathrm{~km}$ S of Cape Barrow, 1350'45"S, 13559'53"E, Northern Territory, Australia, 16 Oct. 1996.

Tree to $16 \mathrm{~m}$ tall; old outer bark white to brown, new bark reddish, soft, papery. Branchlets glabrescent, with an outer layer of pubescent hairs and a very dense understorey of lanuginulose hairs. Leaves alternate, distinctly dorsiventral, 70-160 $\mathrm{mm}$ long, $12-28 \mathrm{~mm}$ wide, $3.8-8.8$ times as long as wide;

\footnotetext{
Australian National Herbarium, CSIRO Plant Industry, GPO Box 1600, Canberra, ACT 2601, Australia;

corresponding author e-mail: Lyn.Craven@csiro.au.

2 Northern Territory Herbarium, PO Box 496, Palmerston, NT 0831, Australia.
}

petiole 5-12 $\mathrm{mm}$ long; blade glabrescent, the indumentum as on the branchlets but pubescent hairs less frequent, narrowly elliptic, subfalcate or falcate, in transverse section transversely linear, the base narrowly cuneate or cuneate, the apex acute, narrowly acuminate or sometimes obtuse; the apex recurved, the venation of 5-7 longitudinal veins; oil glands obscure, scattered. Inflorescence a spike of triads, usually in the axils of distal leaves, occasionally several occurring at a branchlet apex (with some in the axils of the distal leaves and the others apparently terminal), sometimes the inflorescences are below the leaves, the rachis indumentum with pubescent and lanuginulose hairs, (17-)20-30 mm wide, with 10-15 triads. Hypanthium glabrescent, or remaining hairy, the indumentum with pubescent and lanuginulose (sometimes only pubescent hairs present), broadly vase-shaped or cup-shaped, 3-4 mm long, 3-4 mm wide. Calyx lobes 5, connate at the base, abaxially hairy, not costate, herbaceous in the proximal-central zone and scarious in a broad marginal band, the band c. $0.2 \mathrm{~mm}$ wide, very broadly triangular, $0.7 \mathrm{~mm}$ long. Petals glabrous (a few sparse cilia sometimes present), obscurely clawed, subcircular, 2.5-3.5 mm long. Stamens in 5 distinct bundles, or occasionally solitary free stamens occur between the bundles, 5-7 per bundle; filaments glabrous, white, $7-11 \mathrm{~mm}$ long, bundle claw 2-2.5 mm long; anthers oblong or elliptic, $0.7-1.1 \mathrm{~mm}$ long. Ovary wall adnate to the hypanthium for the proximal one-half, 3-locular; style glabrous, 7.5-11 mm long; ovules c. 40-120 per locule. Fruit not early dehiscent and apparently persisting for 1 year or more, cup- or squat barrel-shaped, $2-3.5 \mathrm{~mm}$ long, $3.3-5 \mathrm{~mm}$ wide, $0.6-0.8$ times as long as wide, $1.8-2.5 \mathrm{~mm}$ wide at the orifice. Seed angular narrowly obovoid, $0.8-1 \mathrm{~mm}$ long, testa membranous, cotyledons about half the length of the embryo, obvolute.

Distribution - Australia (Northern Territory, floodplain and coastal swamp regions in the Top End).

Habitat \& Ecology - Recorded as occurring on low areas beside billabong, in swale of coastal dunes, as scattered trees on floodplain, in seasonal sandy swamp, on outer edge of riparian forest, on levee bank beside creekline, in paperbark woodland, on a sandy chenier ridge, on a sandy drainage flat, and as forming a community near mangroves; usually in 
seasonally inundated habitats. Flowering: September, October; fruiting: most months.

Specimens studied. Barritt \& Wightman 1932, Brocklehurst 648, Brocklehurst \& Dunlop 456, 457, Cameron s.n. 1/10/1973, Cowie 7335 (type), Cowie \& Mangion 7717, 7955, Dunlop \& Cowie 9482, Dunlop \& Taylor 6185, Dunlop \& Wightman 9246, 9769, Scarlett 141, Waterhouse 9842, Waterhouse \& Burgman 9602, Waterhouse \& Sanderson 9528, Wightman $734,1632,7000$

Notes - 1. In ethnobotanical accounts of flora in the Northern Territory, this species is treated under the name 'Melaleuca sp. nov.', 'Melaleuca sp. (D120590)' and 'Melaleuca sp. ('red bark', D120590)' (Yunupingu et al. 1995, Blake et al. 1998, Puruntatameri et al. 2001; G. Wightman pers. comm.). In a floristic list of plants in the Alligator Rivers region of the Northern Territory, the species is listed as Melaleuca sp. D20720 (Brennan 1996). The specimen Waterhouse 9842 is listed as Melaleuca sp. nov. by Waterhouse \& Puttock (1981) in their list of vascular plant species on the Jabiluka area, Northern Territory. Melaleuca ferruginea, as circumscribed above, apparently includes at least part of the taxonomic concept of the unpublished name $M$. dealbata subsp. glabrescens Barlow.

2. The specific epithet is derived from the Latin ferrugineus, rusty, light reddish brown, and refers to the new bark colour of this species.

3. Kenneally 10737, from near Broome in the Kimberley region of Western Australia, may also be referable to this species.

\section{Melaleuca nervosa (Lindl.) Cheel}

Melaleuca nervosa (Lindl.) Cheel (1944) 65. - Callistemon nervosum Lindl. (1848) 235. - Melaleuca leucadendron (L.) L. var. ? parvifolia Benth. (1867) 143, p.p. (as to C. nervosus). - Melaleuca leucadendron (L.) L. var. nervosa (Lindl.) Domin (1928) 457, nom. illeg. - Type: Mitchell 241 (holo CGE n.v.; iso BRI fragm, K, MEL, NSW n.v.), Australia, Queensland, Balmy Creek, July 1846.

Melaleuca crosslandiana W.Fitzg. (1906) 10. - Melaleuca leucadendron (L.) L. var. coriacea forma crosslandiana (W.Fitzg.) Cheel (1917) 298. - Melaleuca nervosa (Lindl.) Cheel subsp. crosslandiana (W.Fitzg.) Barlow ex Craven (1999) 23. - Type (fide Blake (1968) 43): Fitzgerald 1116 (lecto NSW; isolecto BRI), Australia, Western Australia, base of Mt Harris, June 1905.

Melaleuca nervosa (Lindl.) Cheel forma latifolia Byrnes (1984) 74. - Type: Blake 16344 (holo BRI), Australia, Northern Territory, about SE of Brocks Creek, July 1946.

Note - There is too great a degree of overlap in morphological features to warrant the continued recognition of $M$. crosslandiana at any rank. The only non-overlapping feature that serves to distinguish $M$. crosslandiana from $M$. nervosa apparently is the occurrence of appressed hairs on the branchlets and leaves in the former species, and even this is not constant with spreading-ascending hairs also occurring. Both species have lanuginulose hairs on the branchlets and leaves.

\section{KEY TO THE MELALEUCA LEUCADENDRA SPECIES GROUP (based on Craven 1999)}

1. Staminal filaments hairy $\ldots . . .$. M. lasiandra F.Muell.

1. Staminal filaments glabrous . . . . . . . . . . . 2

2. Hypanthium distinctly hairy (at least in bud) . . . . . 3

2. Hypanthium glabrous or effectively so . . . . . . 18

3. Leaf blade indumentum with at least some of the hairs lanuginulose or sericeous-lanuginulose (whether or not also with pubescent to sericeous or sericeous-pubescent hairs)

3. Leaf blade indumentum without lanuginulose or sericeouslanuginulose hairs (the hairs sericeous, sericeous-pubescent or pubescent) $\ldots \ldots \ldots \ldots \ldots \ldots \ldots \ldots \ldots \ldots$
4. Calyx lobes very broadly triangular $(0.7 \mathrm{~mm}$ long $) \ldots \ldots$ . . . . . . . . . . . . . . ferruginea Craven \& Cowie

4. Calyx lobes broadly ovate, ovate, subcircular or triangular $\ldots \ldots \ldots \ldots \ldots \ldots \ldots \ldots \ldots \ldots \ldots \ldots \ldots \ldots \ldots \ldots \ldots \ldots \ldots$

5. Stamens $5-8 \mathrm{~mm}$ long $\ldots \ldots \ldots \ldots \ldots \ldots$

5. Stamens $10-25 \mathrm{~mm}$ long . . . . . . . . . . 7

6. Calyx lobes $0.5-0.8 \mathrm{~mm}$ long; triads clustered (less than 1 hypanthium diameter apart) ..... M. saligna Schauer

6. Calyx lobes $0.9-1.5 \mathrm{~mm}$ long; triads scattered (more than 1 hypanthium diameter apart) or sometimes partly clustered

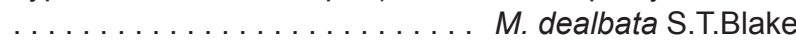

7. Calyx lobes $1.9-2.5 \mathrm{~mm}$ long; petals $5.1-7 \mathrm{~mm}$ long ... ..................... M. triumphalis Craven

7. Calyx lobes $0.5-1.5 \mathrm{~mm}$ long; petals $1.5-3.5 \mathrm{~mm}$ long 8

8. Leaf oil glands more or less in rows; leaves 5-20 times as long as wide, the blade 5-19 mm wide; hypanthium 1.3-2 mm long; stamens 3-9 per bundle . . M. fluviatilis Barlow

8. Leaf oil glands scattered; leaves 1.6-10.2 times as long as wide, the blade $5-40 \mathrm{~mm}$ wide; hypanthium $1.8-3.5$ mm long; stamens 3-7 per bundle

M. nervosa (Lindl.) Cheel

9. Inflorescence up to $30 \mathrm{~mm}$ wide . . . . . . . . . . 10

9. Inflorescence more than $30 \mathrm{~mm}$ wide . . . . . . . . 17

10. Inflorescence up to $20 \mathrm{~mm}$ wide . . . . . . . . . 11

10. Inflorescence more than $20 \mathrm{~mm}$ wide . . . . . . . 13

11. Triads scattered (at least 1 hypanthium diameter apart, sometimes within an inflorescence some of the triads are closer) . . . . . . . . . . . M. stenostachya S.T.Blake

11. Triads clustered (less than 1 hypanthium diameter apart)

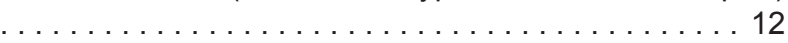

12. Leaf blade apex acuminate, narrowly acute or acute ... M. sericea Byrnes

12. Leaf blade apex usually obtuse, sometimes acute, rounded, obtusely shortly acuminate or retuse

M. arcana S.T.Blake

13. Calyx lobes herbaceous in the proximal-central zone and scarious in a narrow marginal band; leaves 4.8-14 times as long as wide . ........... argentea W.Fitzg.

13. Calyx lobes herbaceous in the proximal-central zone and scarious in a broad marginal band; leaves 1.3-9.7 times as long as wide . . . . . . . . . . . 14

14. Older leaves with the secondary venation distinct and about as prominent as the major veins . . . . . . . . 15

14. Older leaves with the secondary venation more or less obscure . . . . . . . . M. quinquenervia (Cav.) S.T.Blake

15. Leaves (17-)25-50(-60) $\mathrm{mm}$ wide (leaves $1.3-6.5$ times as long as wide; stamens (8-)9-12(-15) per bundle. . .

. M. cajuputi Powell subsp. platyphylla Barlow

15. Leaves (6-)10-28(-39) $\mathrm{mm}$ wide . . . . . . . 16

16. Leaves (6-)10-16(-26) $\mathrm{mm}$ wide, $2.8-9.7$ times as long as wide; stamens (6-)8-11(-14) per bundle . . . . . . . ................ cajuputi Powell subsp. cajuputi

16. Leaves (15-)19-28(-39) mm wide, 2.2-2.9 times as long as wide; stamens $(4-) 6-8(-10)$ per bundle) . . . . . . . M. cajuputi Powell subsp. cumingiana (Turcz.) Barlow

17. Young shoots with the hairs completely appressed; hypanthium (1.8-)3-3.5 mm long; petals (2.7-)4-5.3 mm long; inflorescence axis sericeous or pubescent (occasionally glabrous) . . . . . . . . . . . M. viridiflora Sol. ex Gaertn.

17. Young shoots with at least some spreading-ascending to spreading hairs; hypanthium $1.5-2.5 \mathrm{~mm}$ long; petals 2.5-3.5 mm long; inflorescence axis pubescent ...... M. quinquenervia (Cav.) S.T.Blake 
18. Calyx lobes puberulous on the abaxial surface ....... ... . . . . . . . . . . . . . . M. dealbata S.T.Blake

18. Calyx lobes glabrous on the abaxial surface . . . . . 19

19. Calyx lobes herbaceous in the proximal-central zone and scarious in a narrow marginal band or the lobes herbaceous almost throughout . . . . . . . . . . . . . 20

19. Calyx lobes herbaceous in the proximal-central zone and scarious in a broad marginal band $\ldots \ldots \ldots \ldots \ldots 21$

20. Stamens 6-7 mm long; leaves 30-110 mm long, 3.3-9 times as long as wide; bark hard. . . M. clarksonii Barlow

20. Stamens 7-16 mm long; leaves 75-270 mm long, 3.5-16.1 times as long as wide; bark papery M. leucadendra (L.) L.

21 . Leaf blade narrowly ovate, very narrowly ovate, rarely narrowly elliptic or very narrowly elliptic (often falcate to subfalcate); leaves 3.5-16 times as long as wide; petals with elliptic oil glands (occasionally long elliptic glands form an apparently linear gland) .......M. leucadendra (L.) L.

21. Leaf blade elliptic to very narrowly elliptic, obovate to very narrowly obovate (rarely broadly elliptic or ovate or very narrowly ovate or approaching falcate); leaves usually 1.3-8.5 times as long as wide (in some forms of M. viridiflora 4.8-15.7 times as long as wide with the blade very narrowly elliptic or narrowly elliptic or narrowly to very narrowly obovate); petals with linear, elliptic, circular to subcircular, or oblong oil glands . . . . . . . 22

22. Stamens $9.2-10 \mathrm{~mm}$ long, the bundle claw $0.2-0.4$ times as long as the stamens . . . . . . . . . . . . . . .......... M. cajuputi Powell subsp. platyphylla Barlow

22. Stamens (9.5-)10.5-23 mm long, the bundle claw $0.06-$ $0.2(-0.5)$ times as long as the stamens . . . . . . 23

23. Hypanthium (1.8-)3-3.5 mm long; petals (2.7-) $4-5.3 \mathrm{~mm}$ long; inflorescence axis sericeous or pubescent (occasionally glabrous) . . . . . . . . . . . viridiflora Sol. ex Gaertn.

23 Hypanthium 1.5-2.5 mm long; petals 2.5-3.5 mm long; inflorescence axis pubescent .............. $\ldots . . . . . . .$. M. quinquenervia (Cav.) S.T. Blake

Acknowledgements Kirsten Cowley and Anna Monro are thanked by LAC for their willing cooperation in locating literature, printing documents, etc. during a period in which he was away from the herbarium. The directors and curators of the herbaria CANB, DNA and UNSW are thanked for the opportunity to examine collections in their care.

\section{REFERENCES}

Bentham G. 1867. Melaleuca. In: Flora Australiensis 3: 123-163. Reeve \& Co., London.

Blake NM, Wightman G, Williams L. 1998. Iwaidja ethnobotany. Northern Territory Botanical Bulletin 23: 1-162. Parks \& Wildlife Commission Northern Territory, Darwin.

Blake ST. 1968. A revision of Melaleuca leucadendron and its allies (Myrtaceae). Contributions of the Queensland Herbarium 1: 1-114.

Brennan K. 1996. An annotated checklist of the vascular plants of the Alligator Rivers Region, Northern Territory, Australia. Supervising Scientist, Barton. Byrnes N. 1984. A revision of Melaleuca L. (Myrtaceae) in northern and eastern Australia, 1. Austrobaileya 2: 65-76.

Cheel E. 1917. Myrtaceae of Northern Territory (except Eucalyptus). In: Ewart AJ, Davies OB, The flora of the Northern Territory: 290-304. McCarron, Bird \& Co, Melbourne.

Cheel E. 1944. Notes on the nomenclature and taxonomy of certain species of Melaleuca. Journal of the Proceedings of the Royal Society of New South Wales 78: 63-66.

Craven L. 1999. Behind the names: the botany of Tea tree, Cajuput and Niaouli. In: Southwell I, Lowe R, Tea tree: the genus Melaleuca: 11-28. Harwood Academic Publishers, Amsterdam.

Domin K. 1928. Melaleuca. Bibliotheca botanica 89: 455-458.

Edwards RD, Craven LA, Crisp MD, Cook LG. 2010. Melaleuca revisited: cpDNA and morphological data confirm that Melaleuca L. (Myrtaceae) is not monophyletic. Taxon 59: 744-754.

Fitzgerald W. 1906. Melaleuca crosslandiana. Western Mail (Perth) 21 (1066): 10

Lindley J. 1848. Callistemon nervosum. In: Mitchell TL, Journal of an expedition into the interior of tropical Australia: 235. Longman, Brown, Green \& Longmans, London.

Puruntatameri J, Puruntatameri R, Puruntatameri A, Burak L, Tipuamantymirri C, Tipakalippa M, Puruntatameri J, Puruntatameri P, Pupangamirri JP. Kerinaiua R, Tipiloura D, Orsto M, Kantilla B, Kurrupuwu M, Puruntatameri PF, Puruntatameri TD, Puruntatameri L, Kantilla K, Wilson J, Cusack J, Jackson D, Wightman G. 2001. Tiwi plants and animals. Northern Territory Botanical Bulletin 24: 1-191.

Waterhouse JT, Puttock CF. 1981. Species of vascular plants of the Jabiluka are. In: Morley AW (ed), A review of Jabiluka environmental studies: unpaginated. Pancontinental Mining Ltd, Sydney. [Unpublished report. Copies held in two Northern Territory government libraries.]

Yunupingu B, Yunupingu-Marika L, Marika D, Marika B, Marika B, Marika R, Wightman G. 1995. Rirratjingu ethnobotany: Aboriginal plant use from Yirrkala, Arnhem Land, Australia. Northern Territory Botanical Bulletin 21: $1-112$. 